\title{
SMAD2 wt Allele
}

National Cancer Institute

\section{Source}

National Cancer Institute. SMAD2 wt Allele. NCI Thesaurus. Code C52819.

Human SMAD2 wild-type allele is located in the vicinity of 18q21.1 and is approximately $93 \mathrm{~kb}$ in length. This allele, which encodes mothers against decapentaplegic homolog 2 protein, plays a role in the potentiation of transforming growth factor-beta signaling; and thus, regulates cellular proliferation, apoptosis, and differentiation. 